\title{
A comédia urbana: de Robert Macaire à Lanterna Mágica. Representações e práticas comparáveis na imprensa ilustrada no século XIX - entre o romantismo e o realismo
}

Heliana Angotti-Salgueiro

Resumo: Estudo comparativo entre a série de caricaturas de Honoré Daumier, "Les Robert Macaire", e as do folhetim A Lanterna Mágica, atribuídas a Manuel de A. Porto-Alegre. A apropriação evidencia-se na forma e no sentido da crítica dos costumes, da política, da corrupção e das situações cotidianas, temas atemporais, de significativa atualidade. Palavras-chave: caricaturas, história sociocultural, vida urbana, modelos franceses no Brasil.

Abstract: Comparative study between a series of caricatures of Honoré Daumier, "Les Robert Macaire", and the feuilleton A Lanterna Mágica, attributed to Manuel de A. Porto-Alegre. The authorship of A Lanterna Mágica is evidenced by the form and meaning expressed in the criticism of manners, politics, corruption and everyday situations, themes that are ageless and relevant nowadays. Keywords: caricatures, sociocultural history, urban life, French models in Brazil. 
As pesquisas sobre a sociedade e a cultura vêm confirmando, nos últimos decênios, a importância dos indivíduos, ou "atores sociais" - expressão que já se consagrou na historiografia -, ligados às redes de relações e às experiências de deslocamento, como base para o estudo da transferência, apropriação e recepção de modelos ou da circulação de representações. ${ }^{1}$ No âmbito dessa História deve-se situar a mobilidade dos textos e das imagens na trajetória daqueles que as produziram, ou seja, observando as situações vividas em contextos comuns. ${ }^{2}$ Minhas pesquisas vêm se concentrando há tempos sobre atores sociais no espaço urbano, ou seja, na operação historiográfica pela via das biografias intelectuais dos que partilham situações, modelos e referências semelhantes. Assim, levantei itinerários pessoais esquecidos que colocam questões significativas para se pensar o que acontece com modelos formais franceses no Brasil, num campo vasto que é o da história social e cultural das cidades.

A comparação que proponho, inscrita no estudo da imprensa ilustrada do século XIX, trouxe à luz um dos temas mais fecundos para o estudo da apropriação de modelos do romantismo francês no Brasil, em variante exemplar que evidencia a trama das redes artísticas de uma época. Trata-se da filiação explícita entre A Lanterna Mágica, periódico atribuído a Manuel de Araújo Porto-Alegre e a seu discípulo Rafael Mendes de Carvalho, editado no Rio de Janeiro em 1844-5, e a célebre série de litografias criada por Honoré Daumier, Les Robert Macaire, publicadas primeiramente no Le Charivari a partir de $1836,{ }^{3}$ e que serão em seguida associadas a pequenos textos num livro ilustrado, Les cent-et-un Robert Macaire, intercalando episódios escritos por Maurice Alhoy e Louis Huart, autores que praticavam a literatura ilustrada, tão própria dos anos 1830-50.

1 Agradeço, primeiramente, aos organizadores do Colóquio, professores Cilaine Alves Cunha e Vagner Camilo, a gentileza do convite para retomar partes de minha pesquisa publicada em: A comédia urbana: de Daumier a Porto-Alegre (com colaborações de João Roberto Faria e Ana Maria Kieffer). São Paulo: faap, 2003, por ocasião da exposição internacional homônima de que fui curadora, e que recebeu o apoio da Fundação Armando Álvares Penteado. Reúno aqui algumas reflexões desse texto e partes de conferências proferidas sobre o tema, que me são solicitadas continuamente na França, procurando reforçar nesse texto aspectos histórico-metodológicos das imagens em comparação, das quais apenas uma pequena parte pode ser reproduzida.

2 A vasta bibliografia específica ao tema usada neste trabalho consta no catálogo citado supra. Ver, especialmente em termos do enfoque, o número especial da revista Annales, Histoire et Sciences Sociales, n. 2, 1994, sobre Littérature et histoire, e Bernard Lepetit (Dir.). Les formes de l'expérience. Une autre histoire sociale. Paris: Albin Michel, 1995.

3 A pertinência desta comparação foi apenas sugerida no clássico de Herman Lima, História da caricatura no Brasil. Rio de Janeiro: José Olympio, 1963.

Teresa revista de Literatura Brasileira [12|13]; São Paulo, p. 174-191, 2013 • 175 
Não se trata de uma comparação simplificadora de ponto por ponto, mas da contextualização de visualidades em um mesmo universo cultural, de apropriações parciais tanto do espírito do texto da dupla francesa, quanto, e especialmente, das caricaturas de Daumier, de que Alhoy e Huart por sua vez já haviam se apropriado, reunindo-as nos Les cent-et-un...

Sempre defendo o cuidado com a terminologia nesses casos comparativos - a reter, aqui, um princípio metodológico básico: transferências de discursos e imagens não são mais analisadas hoje sob categorias ultrapassadas como "influência", "derivação", "reflexo”. Ao levar em conta a dimensão histórica de itinerários e práticas comuns a uma geração, apesar das diferenças que sempre existem em vários níveis, enxergamos de outra maneira uma relação comparativa (no caso, entre Daumier e Porto-Alegre), ou seja, em termos de apropriação, citação, referência, nunca de cópia e jamais de influência. ${ }^{4}$ O interesse em comparar as publicações A Lanterna Mágica e Les cent-et-un Robert Macaire é ver a primeira como uma variante da segunda inscrevendo as duas em um mesmo cenário cultural - ao detectarmos as convergências e as singularidades históricas dos personagens, suas experiências semelhantes em contextos diferentes, vamos além da simples "busca das origens".

Nos labirintos da micro-história, muitos atalhos levam-nos a caminhos que se encontram, a objetos que se relacionam, mesmo se procedentes de regimes de historicidade diferentes. Porto-Alegre chega a Paris em 1831, em plena eclosão da imprensa ilustrada; ele acompanha seu mestre Jean-Baptiste Debret (que, sabemos, viveu no Rio de Janeiro desde 1816 como desenhista e pintor da Missão Francesa). Porto-Alegre voltará ao Brasil em 1837, e em 1844 ele coloca em circulação A Lanterna Mágica, álbum anônimo com quinze caricaturas atribuídas a Rafael Mendes de Carvalho sob sua orientação direta ${ }^{5}$ (duas estão assinadas), e 23 cenas ou episódios, em 180

Convido o leitor a ler minha introdução à tradução do livro de Michael Baxandall, Padrões de intenção. A explicação histórica dos quadros. São Paulo: Companhia das Letras, 2006, p. 9-23, em que sublinho a recusa desse autor à noção de "influência", segundo ele "uma das pragas da crítica de arte". O artista e os modelos convocados ou apropriados são temas que permanecem da maior atualidade em história da arte - basta lembrarmos duas recentes exposições na França: Picasso et ses maitres no Grand Palais, no outono de 2008, e Cézanne/Picasso, no verão de 2009, em Aix-en Provence, que colocaram muito bem a questão que vem nos ocupando há anos, em vários campos, sobre as relações entre a França e o Brasil, desde a arquitetura e a história intelectual do urbanismo no século XIX, à fotografia do entreguerras, mais recentemente. Ver resenha de minha autoria sobre os catálogos destas exposições, em futuros números dos Anais do Museu Paulista.

5 A historiografia consagra Araújo Porto-Alegre como autor das primeiras caricaturas feitas no Rio de 
páginas de texto. ${ }^{6} \mathrm{O}$ subtítulo indica ser um periódico plástico-filosófico, mas há mais diálogos do que prosa, e há cartas aos leitores de cunho jornalístico, inexistentes nos Les cent-et-un Robert Macaire.

No estudo das convergências entre o texto-modelo francês e a variante brasileira, observe-se que a estrutura das duas obras é parecida, a fórmula da composição editorial é a do folhetim, uma espécie de fragmentação em partes da história composta de pequenos capítulos que não são obrigatoriamente lineares. Pequenos episódios em sequência, ilustrados por vinhetas, precedidos do título e acompanhados da caricatura correspondente, que se intercala a cada três páginas de texto e efeito de um contraponto, no caso dos Cent-et-un Robert Macaire. Na Lanterna, o espaço ocupado pelo texto varia muito, não há essa sistemática de composição e diagramação uniforme, a numeração dos episódios é confusa, sendo bem menor o número de imagens. Daumier e Porto-Alegre viveram, evidentemente, trajetórias biográficas diferentes; Paris e Rio eram muito diferentes naquela época, como ainda o são hoje; no entanto, o historiador é responsável pela interpretação que constrói, apoiando-se em documentos pertinentes, na seleção de imagens em séries - e associação com outras mídias, como foi o caso da exposição na FAAP, em que objetos tridimensionais, música e teatro dialogaram e enriqueceram o tema: ao fazer a história da Lanterna Mágica, e ao levá-la ao grande público em 2003, procurei não separar os níveis, mas acentuar as relações entre eles, além de sugerir o que representam depois de tanto tempo, destacando seu interesse em relação a temas da atualidade como a corrupção, a denúncia de aproveitadores de toda sorte, de práticas de especuladores e charlatães, do mau caráter dos homens das finanças e de políticos, da crítica social e da miséria, enfim... da "comédia humana". Voltemos à análise comparativa do projeto gráfico. A organização da página ilustrada, com o enquadramento ornamentado da cena, apresenta um medalhão na parte superior que encerra o título da série e o número do episódio, e outro medalhão maior na parte inferior da página para a legenda - essa apresentação se repete com variações em outros livros ilustrados ou nas inúmeras séries de estampas que circularam na época (alguns exemplos: Gavarni, séries dos Bal masqué e Fantaisies,

Janeiro; as que restaram e em mau estado de conservação são "A campainha e o Cujo" e "A Rocha Tarpeia", que satirizam o cronista José Joaquim da Rocha, e "Estado de um eleitor em 1839". Sobre elas Soares de Souza escreveu que só podiam ter sido feitas "por quem conhecesse Daumier e Gavarni". Elas figuraram na exposição A comédia urbana. Ver a reprodução e meus comentários no catálogo citado, p. 77-81.

Encaminhei a algumas editoras a proposta de se fazer um fac-símile com uma introdução analítica deste raro periódico (um único exemplar completo encontra-se na Biblioteca Nacional do Rio de Janeiro, e foi mostrado na exposição). 
Daumier, Mésaventures et mésapointments de M. Gogo, dos dois com Victor Adam, Le musée pour rire (cujo texto era também de Huart e Alhoy), e, entre nós, o álbum de Johann Jacob Steimann, Souvenirs de Rio de Janeiro, em 1835).

É por isso que, além das similitudes específicas que resultam da apropriação feita por Araújo Porto-Alegre da série dos Robert Macaire de Daumier, trata-se aqui de associá -los a outros nomes contemporâneos, numa rede de correspondências que os articula entre si. De Daumier a Porto-Alegre passamos por Charles Philipon, Paul Gavarni, Henri Monnier, Grandville e outros desenhistas e litógrafos, sublinhando sua associação à crítica de costumes das cenas de La comédie humaine de Honoré de Balzac: evidência que justifica, entre outras, o título que demos à exposição que se seguiu à pesquisa. Numerosos temas se repetem nas séries colocadas em paralelo, ramificações de episódios diferentes colocam em cena os mesmos personagens, cuja dinâmica forma um panorama social do século XIX (para lembrar uma expressão de Walter Benjamin). Porto-Alegre é entre nós um estudo de caso ideal, por sua participação no universo da cultura oitocentista do Rio, onde ele se liga a diversas instituições e campos - das artes visuais (é pintor, desenhista e arquiteto) à literatura, passando pela história e a geografia, a crônica, a crítica de arte, a música e o teatro, sendo conhecido autor de numerosas peças e de cenografias. Foi também responsável por um pensamento patrimonial precoce e por tomadas de posição nacionalistas junto a instituições como a Escola de Belas Artes, o Instituto Histórico e Geográfico, combates em que tentava cumprir sua "missão" de civilizar seu país, apesar dele.

Reconhecemos em Porto-Alegre um representante típico da pluralidade cultural dos homens de seu tempo, com competências múltiplas - a maleabilidade de pertencimento dos indivíduos a grupos sociais diversos da sociedade urbana da época era comum, bem como a curiosidade intelectual. (A contextualização dos textos de Porto-Alegre em função da diversidade mesma dos temas que ele tratou ainda está por ser feita - foi leitor de Montesquieu, Jean-Baptiste Say, Humboldt, Michel Chevalier, Saint-Simon, Comte de Laborde, ${ }^{7}$ autores dos quais se apropria na busca de soluções para os problemas do Brasil.) Esta pluralidade de competências nutrida pelo homem do século xix exige do pesquisador de hoje abertura e conhecimentos interdisciplinares. A Lanterna Mágica é uma pequena parte de sua obra, que ficou esquecida nos anais da história oitocentista, mas que caracteriza um período em que não se pode mais pensar em isolamento cultural. Ela se afigura como a síntese de um

Entre esses textos, "Bellas Artes". In: Relatório da Commissão Brazileira na Exposição Universal de Paris. Apresentação de J. Constâncio (Conde de Villeneuve). Rio de Janeiro: Typ. Claye, 1868. 
tempo em que a cidade é um lugar de práticas, cujas relações comparadas podem ser estabelecidas em vários níveis.

O próprio título "A Lanterna Mágica" é uma metáfora alusiva ao instrumento de projeção de imagens em cenas sucessivas, inventado no século Xvir e muito popular na cultura visual do XIX - era um espetáculo para todo tipo de público, uma espécie de "combinação original de imagens, sons, diálogos que se relaciona com a história do livro ilustrado, [e precede] o desenho animado e o cinema - do audiovisual à multimídia, essas linguagens visuais do século $\mathrm{xx"}{ }^{8}$

“Lanterne Magique" é também o título de panfletos revolucionários que voltam ao longo do século, ainda que com outros objetivos além dos políticos - o divertimento e a instrução predominam, na França, a partir de 1835. Obras posteriores no Brasil retomam o significado e a alusão: no frontispício da Semana Ilustrada nos anos 1860, o caolho de chapéu emplumado e trajes de bufão cercado de figurinhas e personagens (como na vinheta do Le Charivari, dos anos 1830) faz funcionar uma lanterna mágica com a ajuda de Mefistófeles, que empurra a lâmina onde se lê "ridendo castigat mores" - lembremo-nos que a divisa de La Caricature era "castigat ridendo mores"... $\mathbf{O}$ gênero do folhetim brasileiro difere da maioria das revistas ilustradas, pois há um narrador que apresenta a obra por meio de uma Carta ao leitor, anunciando as cenas como aquele que andava pelas ruas e balançava sua lanterna mágica anunciando o espetáculo. A conhecida imagem do Diable à Paris (publicado de 1843 a 1846), do homem em negro que caminha sobre o mapa de Paris carregando às costas um cesto pleno de panfletos ou impressos, com a lanterna na mão, era certamente conhecida de Araújo Porto-Alegre, que, no seu prefácio aos leitores, se refere à identidade do seu Macaire - chamado Laverno, como uma espécie de Mefistófeles, de judeu errante, presente sempre em todo lugar, nas "praças, nos templos, nos salões dourados, no parlamento, nas estalagens, nas lojas, e nos ranchos das estradas". A imagem do diabo aparece nas fantasmagorias dos espetáculos de lanterna mágica (uma placa de vidro dos acervos da Cinemateca Francesa exibe justamente "a recepção de Robert Macaire no inferno: Lúcifer e sua corte”). O sentido que Porto-Alegre dá à lanterna mágica é o de um instrumento que exibe a verdade com todas as suas luzes, e não de um instrumento criador de ilusões - conceitualmente se aproximaria de uma litografia de Daumier, de 1869, que mostra a França segurando uma lanterna mágica que ilumina a clareza de um escrutínio.

fig. 1 Lanterna mágica quadrada fabricada em Paris por A. Lapierre e E.-V. Lapierre, C. 1860. Paris, Cinemathèque Française 


\section{O universo da imprensa ilustrada}

A imagem ocupa um novo lugar no impresso a partir dos anos 1830 graças aos progressos técnicos. A geração de Porto-Alegre participou do começo da era da comunicação visual e da dessacralização da arte pela imprensa ilustrada. Les cent-et-un Robert Macaire e a Lanterna Mágica inscrevem-se assim num universo em que ela assume uma importância crescente: revistas, periódicos, estampas, textos em série constituem um traço de sociedade que gravita nas cidades, em um tempo dominado pela imagem, por uma literatura a vapor (como ilustra a figura da presse mécanique, no popular Magasin Pittoresque, em 1834), por novos gêneros literários, cartazes, prospectos e circulares, pequenas macedônias, caos de pequenas figurinhas, muitas vezes sem ambição estética e sofisticação - caricaturas de todo mundo - universo acolhido com entusiasmo pelas multidões nas ruas e nos teatros, tão bem representado por Daumier. Os folhetins que examinamos constituem uma literatura formada por pequenos textos semeados por ilustrações, que se destinam aos que não têm muito tempo para ler, como nos espetáculos improvisados das lanternas mágicas.

As litografias são popularizadas na França a partir dos anos 1830 por Aubert, que difundia as estampas de Daumier, e por Charles Philipon, editor de álbuns e jornais (La Caricature e depois Le Charivari). A venda de caricaturas dos Robert Macaire, também em séries "coloridas com afinco", era anunciada no jornal Le Charivari, o periódico de contestação mais popular e importante da Monarquia de Julho (1830-40). A cultura urbana do período é representada nesses jornais, em panfletos e fascículos que passavam de mão em mão, certamente apreciados por um público inculto e ávido por novidades...

Neste espírito, há outras séries como a de Philipon, em 1829: Spéculateurs de la bêtise public... - "especuladores da ignorância pública" que distribuíam panfletos para anunciar alguma coisa, vender o que fosse etc.

No espaço urbano, além destes spéculateurs, observa-se a affichomanie (termo da época), que significa a mania de cartazes, de anúncios pitorescos colados ou pintados nas paredes da cidade. Em um dos episódios de A Lanterna Mágica, Laverno, o personagem "Macaire" de Porto-Alegre, refere-se a "cartazes monstros, à maneira de Paris...", e evoca a importância da propaganda pessoal, de "artigos fosforescentes" em jornais, destacando sua "força [em] país onde o mais escoimado pelintra" tem crédito...

A comparação entre A Lanterna Mágica, publicada em 1844-5, e Les cent-et-un Robert Macaire, publicado em 1839 (mas cujas litografias, vimos, circulavam antes nos jornais), se impõe pela evidência formal de diagramação (o enquadramento e 
a composição gráfica são semelhantes, como já observamos) - mas o principal a comparar é a presença dos dois personagens - o malandro espertalhão e seu acólito ou empregado - e a temática comum, a sátira política e moral no cotidiano urbano, encarnada em diversas profissões.
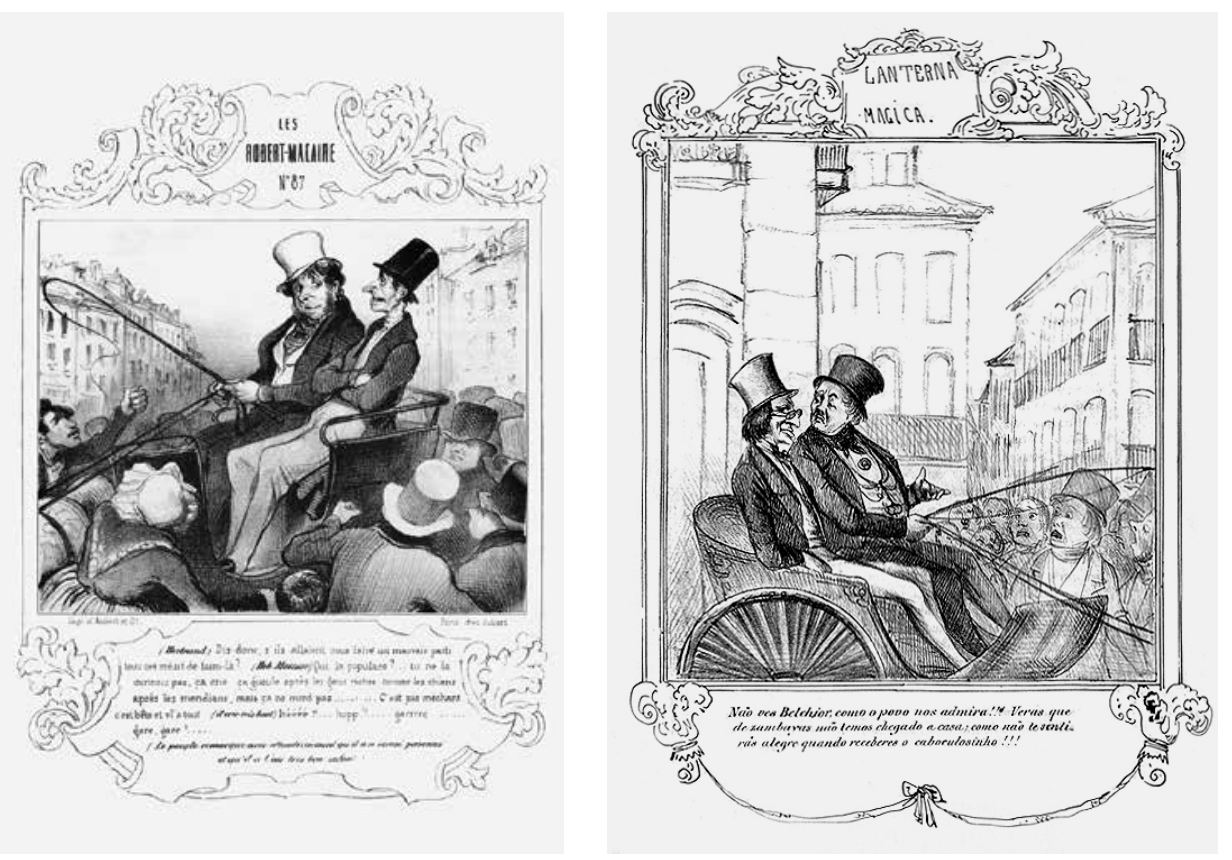

Duas imagens, cuja semelhança é evidente em vários pontos, representam os dois personagens - Robert Macaire e Bertrand na França, e Laverno e Belchior, no Brasil - dentro de uma charrete, no meio da multidão, em cena ambientada na cidade; detecta-se aí, porém, uma grande diferença: a do estilo dos prédios - Paris, com seu largo bulevar e seus imóveis Louis Philippe, e o Rio imperial, com os casarões coloniais amontoados na estreiteza do espaço urbano.

Porto-Alegre vivera em Paris a partir de 1831 e não voltará ao Brasil antes de 1837; sua obra em 1844 mostra que ele, além de ter vivenciado o mesmo universo cultural de Daumier, de Philipon, de Honoré de Balzac, que publicava então sua Comédie humaine, passou pelo ateliê do pintor Antoine-Jean Gros, igualmente frequentado por Philipon, e entendeu a importância comercial da imprensa ilustrada naquele momento, encarnando a nova profissão de editor de periódicos, de estampas etc. fig. 2 Honoré Daumier (desenho) e Charles Philipon (legenda). Les cent-et-un Robert Macaire, Paris, 1839-40. - Biblioteca da Maison de Balzac, Paris

fig. 3 Manuel de Araújo Porto-Alegre (texto) e Rafael Mendes de Carvalho (desenho). A Lanterna Mágica, Rio de Janeiro, 1844. Biblioteca Nacional do Rio de Janeiro 


\section{A fisiologia das profissões - charlatanismo e especulação}

Nos Cent-et-un Robert Macaire a ideia e as legendas são de Philipon, e as imagens reduzidas da série de Daumier intercalam os textos de Maurice Alhoy e Louis Huart, que escrevem para uma série de publicações cômicas ligadas à atualidade política, às atividades literárias e ao teatro - mesmo perfil de atividades às quais se dedicará Porto-Alegre. Lembremos que Huart foi um dos autores das Physiologies, pequenos livros que circulam em pleno realismo romântico. É justamente a fisiologia das profissões que é encarnada pela dupla de A Lanterna Mágica, retomando seu modelo francês.

Com a voga do naturalismo no fim do século xviı, aparecem na literatura popular internacional os retratos de tipos urbanos no modelo dos "cris" ou "proclamas" de Paris. Les petits métiers de Paris, os alfabetos das artes e ofícios (os famosos Cris), são também caricaturados. O gênero se prolongará no Segundo Império francês com variações nas imagens de Epinal; já os alfabetos de quadrúpedes e figuras da história natural compõem vinhetas que aparecem no fim de cada episódio da Lanterna. ${ }^{9}$

Na mesma linha também aparece a série de publicações denominada então "encyclopédie morale du XIX ${ }^{e}$ siècle": Les français peints par eux mêmes, Tiroir du diable: Paris et les parisiens, mours et coutumes, caractères et portraits des habitants de Paris, tableau complet de leurvie privée, publique, politique, artistique, littéraire, industrielle, "panorama social" colocado em texto e imagem, como é a pretensão explícita em $A$ Lanterna Mágica, conforme reza seu prefácio.

A vida urbana oferece "mil caminhos diversos" para fazer fortuna, segundo Laverno, o Macaire brasileiro; ele muda de máscara, como já havia mostrado Daumier na sua série, ironizando a fácil ascensão dos charlatães e diletantes: Monsieur Daumier, votre série est une chose charmante, c'est la peinture exacte des voleries de notre époque. Porto-Alegre observa, logo na primeira caricatura do seu folhetim, que a simples ostentação de um nome estrangeiro ou a mudança da sílaba final permite exercer qualquer profissão no Rio sem a menor qualificação: o malandro Laverno torna-se "Monsier Lavernu" ou "Comte Flibustier de Saint Lavern", para exercer o métier de homeopata, ou exibir ares de nobreza francesa, ou ainda de "Signora Lavernelli", para surgir travestido como cantora italiana de ópera. Os personagens são sempre os dois

Identifiquei várias delas com as que existem no Cabinet d'Estampes da Bibliothèque Nationale de France. Ver também: Vignettes. Ornements, attributs de commerce, cul de lampe, allégories, sujets divers, passe-partout etc. 1830-1895. Paris: Ramsay/Caractères, 1986. 

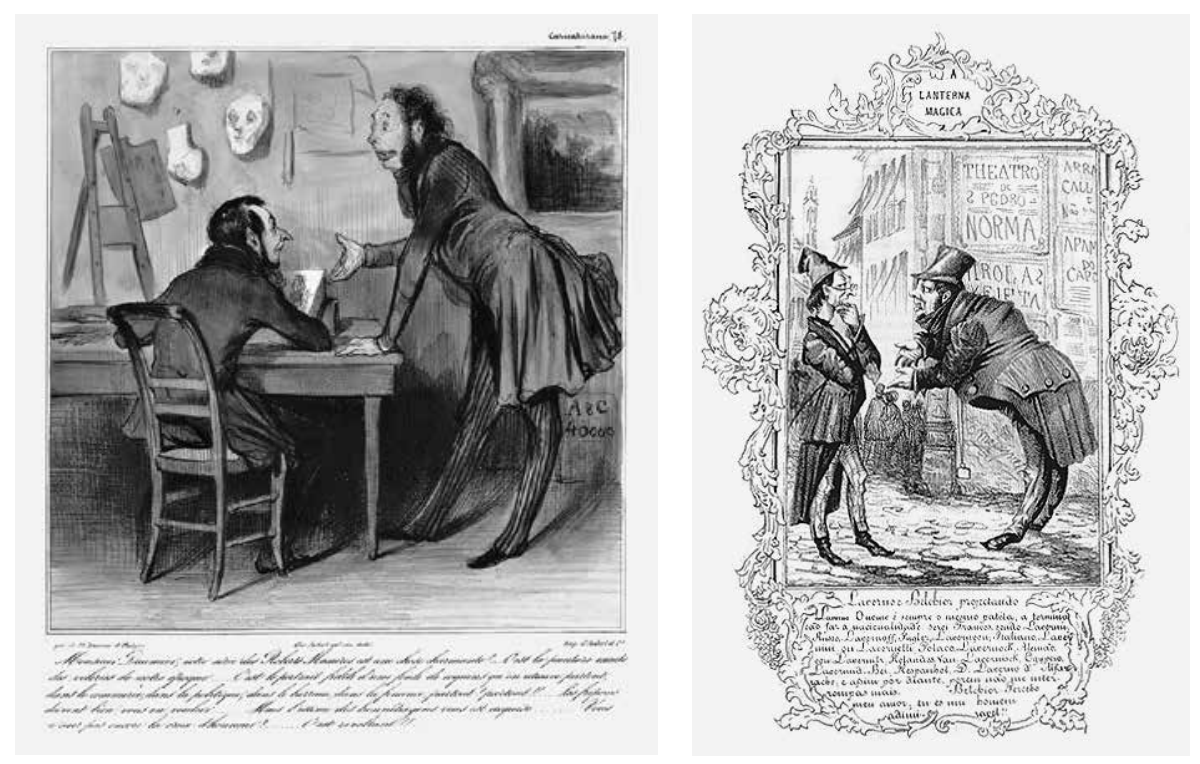

fig. 4 Honoré Daumier (desenho) e Charles Philipon (legenda). Les cent-et-un Robert Macaire, Paris, 1839. Clichê de cortesia Biblioteca da Maison de Balzac, Paris

fig. 5 Manuel de Araújo Porto-Alegre (texto) e Rafael Mendes de Carvalho (desenho). A Lanterna Mágica, Rio de Janeiro, 1844. Biblioteca Nacional do Rio de Janeiro

comparsas, que reaparecem na sequência de situações diversas, como os personagens da Comédie humaine, segundo uma estrutura narrativa de cenas curtas, "projetadas" rapidamente, como nos espetáculos das lanternas mágicas. Laverno, com a ajuda de seu cúmplice servidor, discute com cinismo a estratégia de encarnar em cada cena profissões diversas para enganar os crédulos em frases ricas de metáforas de mutações de caráter.

Os dois, Macaire/Laverno, exploradores de tudo e de todos e por todos os meios, representam a comédia urbana assumindo despudoradamente numerosas identidades profissionais. A alusão simbólica à figura do mercador de roupas fornece o fio da história, ou o sentido do personagem, que também surge no bric-à-brac de objetos e adereços nas litografias dos "tipos modernos" de autoria de Traviès de Villiers nos jornais La Caricature e Le Charivari.

Proteu ou Arlequim, Macaire ou Laverno, torna-se candidato a postos políticos, empresário, maestro, cirurgião, homeopata, jornalista, tipógrafo, escritor, agente matrimonial, professor de "indústria" (de trapaça, malandragem, na língua francesa), acionista, diretor de escola. Em todas as cenas, a palavra de ordem lembra o lema de Guizot: "Enriquecei-vos!".

Fisiologias, abecedários ou alfabetos ilustrados partem de um gesto classificatório segundo Michel Mellot, em uma época "em que as categorias sociais tomam consciência delas mesmas nas grandes cidades". Na caricatura satírica dos retratos-charge 
retomam-se as cenas do cotidiano sob um olhar menos romântico e mais realista do que nos "proclamas" (cris), pois os retratos profissionais da caricatura denunciam as misérias da vida urbana e a hipocrisia de uma sociedade sem escrúpulo, para quem o dinheiro é o denominador comum. Resumindo, as diversas profissões encarnadas para vencer rapidamente na vida são o tema central da representação de Robert Macaire. A cidade do século xıx é um cenário de dificuldades de inserção em um trabalho fixo - cenário de imigração, de ocupações efêmeras e circunstanciais, marcadas pela mobilidade profissional.

Nas cidades (e as do Novo Mundo não fogem à regra, ao contrário), a incompetência e o oportunismo caminham juntos à ingenuidade do público que, no Rio, escreveu Porto-Alegre, concede favores e dá confiança a qualquer pessoa que chega de fora. Conhecem-se suas dificuldades profissionais, sobretudo depois da longa estada em Paris, os múltiplos conflitos em que se envolve com os estrangeiros, especialmente os portugueses na Academia de Belas Artes do Rio. Assim, no texto da Lanterna, ele não estaria ironizando aqueles "aventureiros medíocres" e oportunistas, a quem se dava injustamente colocação? Porto-Alegre refere-se às inúmeras "metamorfoses" geradas pelo "batismo equinocial" de charlatães estrangeiros que ocupavam cargos sem qualificação, e da ingenuidade de seus compatriotas acreditando que eles eram superiores, sendo que muitos brasileiros, além de terem feito estudos no exterior, como ele, ainda conheciam muito bem seu país, quer dizer, mais capazes para ensinar ou dirigir a Academia do que os aventureiros estrangeiros - assim, lê-se em um dos episódios da Lanterna: "A estranja é a melhor panaceia conhecida neste país: chegado dela podes impunemente fazer o que quiseres". Porto-Alegre é vítima de trapaças e calúnias denunciadas indiretamente no folhetim - obra anônima, não por acaso.

As cenas se sucedem ao longo da história, e demonstram a sátira aos negócios "vantajosos", ou seja, desonestos, na ordem do dia naquele "século macaire"; dentre os empreendimentos "lucrativos" denunciava-se, por exemplo, nas charges, tanto na França como no Brasil, a medicina - ciência portadora de ilusões, assimilada ao charlatanismo, em particular a homeopatia, o médico é visto como um mercenário ou um mundano. Daumier fará muitas caricaturas desse profissional (que é também um dos personagens do livro Les français peints par eux-mêmes): a de Robert Macaire de olho na herança do tio doente é comparável à caricatura do falso médico em A Lanterna Mágica (FIGs. 6 e 7). 

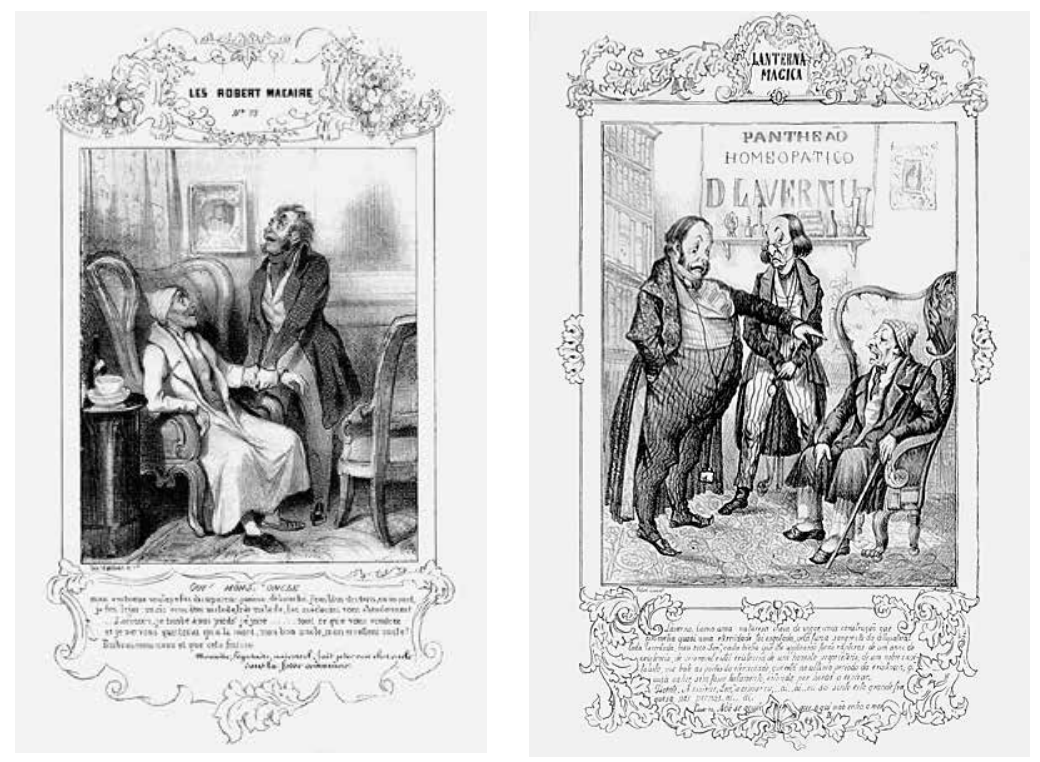

fig. 6 Honoré Daumier (desenho) e Charles Philipon (legenda). Les cent-et-un Robert Macaire, Paris, 1839. Clichê de cortesia Biblioteca da Maison de Balzac, Paris

fig. 7 Manuel de Araújo Porto-Alegre (texto) e Rafael Mendes de Carvalho (desenho). A Lanterna Mágica, Rio de Janeiro, 1844. Biblioteca Nacional do Rio de Janeiro

Retoma-se também na Lanterna a ideia das “consultas gratuitas", porém acompanhadas do gesto enganador da venda de poções miraculosas, que não era nada mais do que a água da fonte da Carioca...

O grotesco estava também em voga quando Porto-Alegre está em Paris, durante a Monarquia de Julho; o repertório de Gavarni, as metamorfoses animalescas de Grandville (os tipos encarnando as Scènes de la vie privée et publique des animaux), e sobretudo os anúncios no Charivari de cours complet de taxidermie ou l'art d'empailler tous les êtres composant le règne animal. Assim, a imagem do charlatão naturalista é encarnada por Laverno, que mata animais diversos e combina-os para criar espécies híbridas, empalhando-os para vendê-los aos museus europeus, que segundo ele eram “ávidos por novidades exóticas" (ele se refere no texto ao seu "museu diabólico"). Os diálogos cínicos e crus do episódio inscrevem-se num realismo moderno também presente no que convencionalmente se etiquetou como "romantismo". Ou seja:

[...] e o que é o mundo senão uma comédia ; os velhacos são os acrobatas, os néscios os palhaços, a mocidade os galãs; a velhice os logrados, e o povo os comparsas (figurantes). A orquestra é todo esse movimento, este zunido de mutucas que se chupam reciprocamente. O ferrão mais duro é o que vence. 
Uma imagem pede para ser observada no seu contexto histórico, um artista na rede de relações de sua época. A análise deve estar atenta à forma, ao tema representado, aos gestos, mas também ao pano de fundo - observando as representações da multidão no espaço urbano em Paris, veem-se as ruas cheias de gente, boêmios saltimbancos, camelôs, "especuladores do público idiota”. A imagem do público estúpido ou ingênuo vem também da série de Daumier - no Brasil esta constatação caminha ao lado, segundo Porto-Alegre, da mediocridade da crítica e da indiferença com as obras de qualidade (a arquitetura, inclusive - lembremo-nos das suas atividades neste ramo). No dicionário Larousse $d u X_{X} x^{e}$ siècle, decênios mais tarde, no verbete Rio Janeiro, há observações sobre as salas de espetáculo e o público teatral.

Embora pessoas nas ruas sejam recorrentes nas cenas, alguns detalhes especificam a variante nacional: nas caricaturas de A Lanterna Mágica, a arquitetura das ruas do Rio, os monumentos esboçados (um deles é o chafariz do Mestre Valentim) indicam o local onde a cena se passa. No Rio também, os tipos locais (os escravos, entre eles) são representados nas cenas de rua, como na litografia em que aparecem ao lado da dupla de "burgueses" malandros, querendo partilhar o ato de fumar, um dos excitantes modernos - e Laverno proclama que o charuto tem "a propriedade de igualar as condições": "Viva o século fumante que dá a Pai Mané Monjolo o gozo, por momentos, do foro de cavalheiro" - enquanto, na litografia de Daumier ("Le chiffonier philosophe", da série Tout ce qu'on voudra), não se trata de status social, mas da dura realidade da condição humana da infância miserável que se expõe: "Fume, fanfan, fume, il n'y a que la pipe qui distingue l'homme du reste des animaux".

A busca de instrução é igualmente uma característica do romantismo; entre as profissões para fazer fortuna há a do professor, ou o que prepara para o baccalauréat (no caso de Robert Macaire), de diretor de liceu (Laverno, no Rio). Há um episódio em que ele aparece "muito ocupado" escrevendo um Tratado de música aplicado às Artes, cujos princípios são a simplificação das regras e a liberdade de composição em nome da "arte ao alcance de todos", discurso típico desse tempo de ecletismo.

Mas nas fisiologias do charlatanismo e da especulação, entre a "multidão de espertinhos que encontramos em todo lugar, no comércio, na política, nas finanças" (cf. uma das legendas de Philipon para os Robert Macaire), o importante é aprender a vencer na vida, ou seja, tornar-se chevalier de l'industrie, isto é, ter habilidade para tirar vantagem de qualquer situação. Porto-Alegre refere-se, por exemplo, aos ladrões artísticos, aos "gênios" praticantes do plágio sem nenhum mérito intelectual, de que ele também foi vítima no Brasil - aos oportunistas que se promovem por 
"cartazes-monstro" (nos muros das cidades, suporte de reclames de toda sorte) ou por polêmicas forjadas na imprensa.

As críticas, porém, à invasão e à banalidade da imagem industrializada são partilhadas por muitos artistas e escritores: em 1842, Balzac se refere, no seu texto da coletânea Le Diable à Paris, à "hipertrofia de um órgão, o olho - l'œil du parisien", que consome as mercadorias e seus ídolos, e que aparece na imagem "surrealista" da "Vênus na Ópera", onde a cabeça dos espectadores é metamorfoseada em olhos gigantes, "devoradores" da musa, no livro genial Un autre monde, de Grandville, em 1844 .

A alusão à cena teatral abre-nos a questão da importância do teatro e da música no universo de A Lanterna Mágica - os suspiros e ohs! do coro dos diletantes diante da cantora lírica, cantarolando a ária "Casta Diva” da ópera Norma de Bellini (tantas vezes mencionada em A Lanterna), na interpretação de Anna Maria Kieffer (que concebeu o CD que acompanha o catálogo), ilustram brilhantemente o espírito da época. ${ }^{10} \mathrm{~A}$ inclusão de partituras em $A$ Lanterna Mágica é, pois, um aspecto significativo e original (voltaremos à questão da música mais adiante). O colega João Roberto Faria, a quem também solicitei um texto, ${ }^{11}$ narra os episódios dos dilettanti, os apaixonados pela ópera no Rio de Janeiro, e, com o reinício dos espetáculos líricos em 1844, as disputas entre os partidários de duas cantoras italianas da época (Candianni e Delmastro), que ocuparam espaço nos jornais; seria por isso que Porto-Alegre introduz a sátira do Laverno travestido de cantora de ópera.

Haveria muito a dizer sobre a relação de Porto-Alegre com o teatro; sabe-se que Porto-Alegre foi autor de várias peças, anos mais tarde. Imprensa, teatro, literatura, música formam então histórias cruzadas de um mesmo universo na Lanterna Mágica, que ironizam as fourberies do cotidiano por metáforas: "Nós viemos ao mundo para representar em uma vasta comédia: é melhor tomar os assentos da frente; e os apoucados que venham atrás".

A figura de Robert Macaire, imortalizada pelo ator Frédérick Le Maître nos teatros populares de Paris a partir de 1834, quando Porto-Alegre lá estava, demonstra o interesse crescente pela sátira cômica em detrimento do melodrama moralista

10 Ver o CD e o texto de Anna Maria Kieffer, "Comédia musical urbana”, que compõem o catálogo A comédia urbana... Op. cit. Catorze músicas inéditas, francesas e brasileiras foram especialmente gravadas para acompanhar a exposição na FAAP e constam desse CD.

11 FARIA, João Roberto. A Lanterna Mágica: imagens da malandragem, entre literatura e teatro. In: ANGOTTI-SALGUEIRO, Heliana. A comédia urbana... Op. cit. 
- o boulevard du Temple, que passa a ser chamado boulevard du Crime em 1825 (nome atribuído pelos jornais populares), foi o berço de nascimento do personagem de Robert Macaire. ${ }^{12}$ Lembremo-nos que, ao voltar para o Rio, Porto-Alegre foi professor de mímica e de declamação do célebre ator João Caetano (que tinha aqui a mesma notoriedade que Frédérick Le Maître em Paris - aliás, o imitava...); mas Porto-Alegre não tardou a criticar seu aluno deslumbrado pelo sucesso fácil, observando que ele não estudou o suficiente, alimentado pelos "aplausos fáceis de um público indulgente".

A presença de canções é um dado interessante neste estudo comparado, pois elas fazem parte, muitas vezes, dos textos ilustrados do romantismo; na pesquisa, encontrei canções da época em Paris e Anna Kieffer as associou às das partituras de $A$ Lanterna Mágica. No CD foram gravadas canções inéditas da Revolução de Julho de 1830 - uma delas chama-se justamente "La Lanterne Magique" - e as das partituras de A Lanterna Mágica, em que a paródia e a sátira do texto se repetem. Reitero que a inclusão de partituras é uma particularidade do folhetim brasileiro - há dois lun$d u s$ (uma mistura de ritmos portugueses e africanos "chamados genericamente de batuques", música nacional que nascia) intercalados ao texto de Porto-Alegre, seu autor, e com música do filho do Pe. José Mauricio Nunes Garcia, além de uma ária lírica "di bravura", ópera-bufa em que Laverno canta travestido de mulher.

A presença do teatro e da música, além de constituir uma originalidade no gênero, confirma a erudição musical de Porto-Alegre, homem de seu tempo, que discute compositores e peças ao longo dos textos: Gluck, Puccini, Donizetti, Atys, Orlando. Uma das caricaturas satiriza as patuscadas (comes e bebes) que se inscrevem na fisiologia do viveur ou do bon vivant, quando seus personagens caem na farra e na bebedeira e cantam o lundu progressista "Fora o regresso", que anuncia um novo tempo, festejando o triunfo fácil da prima-dona improvisada, aplaudida pelo indulgente público do Rio, protótipo da ignorância, segundo Porto-Alegre.

Ver Pierre Gascar, Le Boulevard du Crime. Paris: Atelier Hachette/Massin, 1980. Óleos e gravuras de Adolphe Martial (coleção Wasset, "Ancien Paris") mostram os teatros deste bulevar, quase todos demolidos quando do alargamento da rua no período haussmaniano, em 1862 (o bl. du Crime chama-se hoje bl. Voltaire). O célebre filme de Marcel Carné e Jacques Prévert, Les enfants du paradis (1943), que mostra esse universo do teatro e da rua, foi exibido na FAAP por ocasião da exposição A comédia urbana: de Daumier a Porto-Alegre. Nesse filme clássico, Frédérick Le Maître improvisa a metamorfose do personagem da peça de teatro L'auberge des adrêts, travestido de um burguês esfarrapado e malandro, e deturpa o personagem levando o público ao delírio; Robert Macaire foi então uma criação que se inspirou no personagem daquele ator. 
A exuberância da natureza é outra particularidade das nossas caricaturas trazendo a cor local ao fundo da cena em que Laverno dança com uma mulata o "Lundu dos Lavernos" - dez anos depois Porto-Alegre pintará a tela Floresta brasileira, que nada tem de caricatural, mas que pode ser contemplada como uma expressão da sensibilidade paisagística romântica que persegue Porto-Alegre, expressa nas Brasilianas em 1863.

Ainda na música, as representações de Daumier são diferentes: o título de uma das litografias que fez parte também dos Robert Macaire é "Música pirotécnica, charivarística ou diabólica” - na legenda lê-se: “... não vivemos num tempo de harmonia, é preciso barulho, muito barulho!".

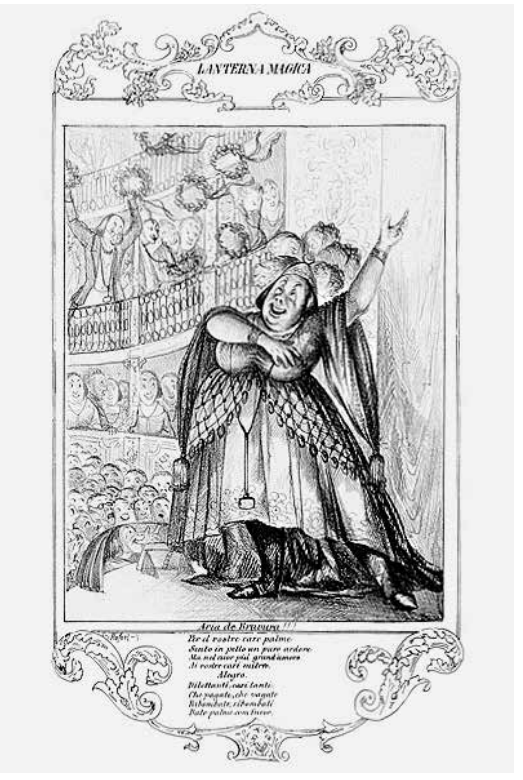

fig. 8 Manuel de Araújo Porto-Alegre (texto) e Rafael Mendes de Carvalho (desenho). A Lanterna Mágica, Rio de Janeiro, 1844. Biblioteca Nacional do Rio de Janeiro

\section{Concluindo...}

A Lanterna Mágica projeta em cada cena a erudição, o pluralismo de curiosidades intelectuais e competências do homem do século XIX representado por Porto-Alegre, que atravessa o Atlântico com a cabeça cheia de imagens e ideias, associando o que viveu às práticas que quer denunciar de maneira realista e sem retórica, "os fatos cotidianos" e corriqueiros da vida urbana do Rio de Janeiro. João Roberto Faria observa que é uma obra inclassificável como gênero, e que se afasta do nacionalismo de louvação do país, tão comum entre os românticos, escolhendo a forma do diálogo (interrompido por vezes com texto narrativo) para expor e criticar certos costumes, comportamentos e tipos sociais. Há uma lucidez na representação da realidade histórica e social que coloca Porto-Alegre além dos românticos. Desconhecem-se as vicissitudes da recepção desta peça de "teatro de papel", a tiragem e os leitores. O projeto inicial era escrever 366 atos (ambição feita mais para ser lida como um folhetim); não se têm tampouco dados sobre desmesurada própria dos românticos, porém interrompida na cena 23. A intenção de fazer dela "uma epopeia do seu tempo" e a promessa de melhorá-la, segundo o dogma saint-simoniano da marcha 
da humanidade para a perfectibilidade, são anunciadas no prefácio - porém, o nosso primeiro periódico ilustrado foi interrompido bruscamente e caiu no esquecimento não triunfando nem no teatro nem na literatura oitocentistas.

A peça é interrompida com a cena da partida repentina de Laverno, escrita, ao que parece, pela necessidade de concluir o folhetim por falta de dinheiro (a Lanterna passou por cinco tipografias em pouco mais de um ano). Nesta última cena o charlatão despede-se afobado de seu amigo e cúmplice, mencionando o convite irrecusável de trabalhar como prima-dona nos teatros do Norte do país, e poder enfim enriquecer e voltar para sua mãe pátria, Gênova. A representação final do Macaire de Daumier é também uma viagem, pois Macaire e Bertrand cruzam a fronteira da França em direção à Bélgica, com os sacos de dinheiro às costas. O mais importante no desfecho da sátira tropical que difere do modelo francês pelo quiproquó da história é a súbita revelação da dupla natureza sexual de Laverno, causada segundo ele por bruxaria, fazendo dele mulher de noite e homem de dia. Sabemos que a ambiguidade dos sexos, ligada tradicionalmente à simbólica do diabo, estava muito em voga na literatura romântica. Laverno confirma assim sua identidade anunciada no prefácio, a de Mefistófeles, que lhe permite estar em todo lugar, de aparecer e desaparecer numa cauda de cometa, lembrando as imagens das fantasmagorias das lanternas mágicas dos espetáculos de rua.

Pode-se concluir que não há classificação disciplinar rígida para a Lanterna Mágica, interessando tanto à história da arte, da literatura, do teatro, da música, do jornalismo, da política, da publicidade e da comunicação visual e das práticas profissionais urbanas - níveis que dialogam entre si na cidade do século XIX. Esta paródia que seu autor pretendia ser uma epopeia patriótica de seu tempo é de fato intemporal pela atualidade de seus heróis sem caráter cujos gestos, atitudes e expressões nada têm de datados, constituindo antes um "retrato da vida moderna". Sob as roupas de sua época, os personagens são de todas as outras épocas, pois as paixões e os crimes que os movem são transistóricos. Sobretudo "nesta terra, em que [como escreveu Porto-Alegre, em memorável frase] andam mais de mil arlequins, vestidos de retalhos de todas as cores e formas, passando por homens superiores". ${ }^{13}$

Cf. Diálogo das cenas 8 e 9 de A Lanterna Mágica. Terminei a comunicação com a imagem de duas caricaturas: a de Granville, La France livré aux corbeaux de toute espèce (A França representada por uma mulher acorrentada e quase morta no chão, à mercê dos "corvos" com faixas honoríficas como as dos políticos...), que saiu em 1831 em La Caricature, e a de Ângelo Agostini, o Índio como São Sebastião, alusão à cidade do Rio de Janeiro, cercada pelos políticos representados por cobras, sapos e morcegos... (Revista 
A erudição e o interesse de Porto-Alegre em estudar e servir ao Brasil não foram reconhecidos e ele foi marginalizado em seu próprio país. Entre polêmicas, demissões e portas que se fechavam, viu-se em situações embaraçosas, sendo alvo de caricaturas anônimas que ridicularizavam um a um seus "combates". ${ }^{14}$ Saíra pelo mundo em busca de conhecimento e, ao voltar ao Rio, desdobra-se em atividades em todas as direções, procurando articular suas contradições e as do seu tempo - dos ideais convencionais e retóricos de elegias oficiais e poemas românticos ao desembaraço de convenções e linguagens expressas no realismo de A Lanterna Mágica, Porto-Alegre chega a um impasse. Parte definitivamente no fim dos anos 1850, desiludido e sem vintém, morrendo na Europa em 1879.

Heliana Angotti-Salgueiro é membro do Núcleo de Pesquisas Brasil-França, no Instituto de Estudos Avançados da UsP. Pesquisadora associada da Chaire Brésilienne en Sciences Sociales Sergio Buarque de Holanda (MSH-CRBC/EHEss, Paris), foi titular entre 2004-2008 e professora visitante de universidades francesas. Doutora em História da Arte, pela École des Hautes Études en Sciences Sociales, ganhou o prêmio da melhor tese do ano de 1992. Fez pós-doutorado pela Getty Foundation (1993) e depois pela Fapesp (1995). Como bolsista Jovem Pesquisador da Fapesp, foi curadora do arquivo Pierre Monbeig no Instituto de Estudos Brasileiros-UsP, entre 1999-2005. Publicou entre outros: La casaque d'Arlequin. Belo Horizonte, une capitale éclectique au XIX ${ }^{e}$ siècle (Paris, 1997); Engenheiro Aarão Reis, o progresso como missão (Belo Horizonte, 1997); é também coautora e organizadora de coletâneas e catálogos, como: Paisagem e arte (São Paulo, 200o), Cidades capitais do século XIX (São Paulo, 2001), Bernard Lepetit: por uma nova história urbana (São Paulo, 2001), A comédia urbana. De Daumier a Porto-Alegre (São Paulo, 2003), Pierre Monbeig e a geografia humana brasileira - a dinâmica da transformação (Bauru, 2006) e Marcel Gautherot e seu tempo. O olho fotográfico (São Paulo, 2007).

Ilustrada, 1888); essas caricaturas inscrevem-se também no registro da transferência de modelo e na longa duração das representações críticas à corrupção.

14 Ver no catálogo A comédia urbana..., op. cit., as caricaturas do "Álbum de Pintamonos"e meus comentários a respeito. 